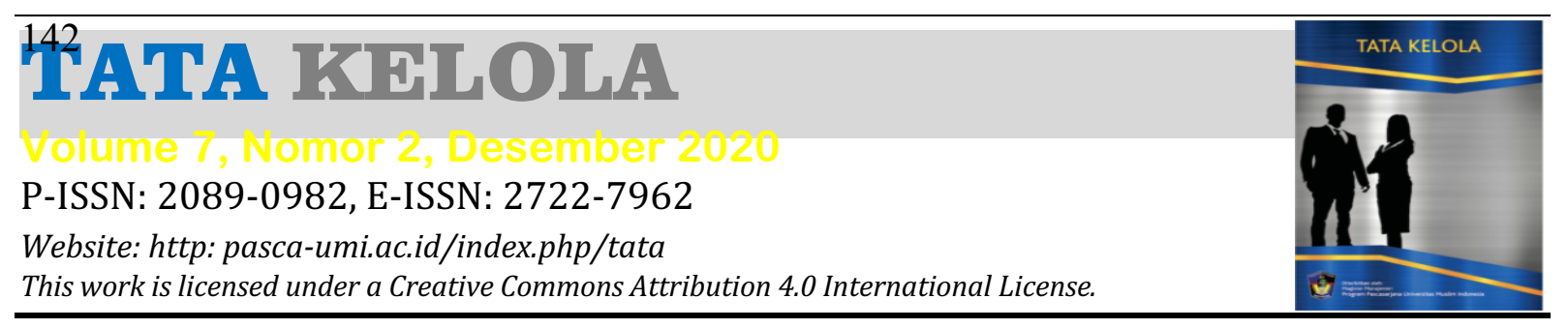

\title{
Pengaruh Pemasaran Digital Terhadap Peningkatan Volume Penjualan Pada Ciputra Tallasa Jo Makassar
}

\author{
Feky Reken ${ }^{1}$, Basri Modding ${ }^{2}$, Ratna Dewi ${ }^{3}$ \\ 1,2,3,4 Magister Manajemen, Universitas Muslim Indonesia. \\ ${ }^{1}$ Koresponden Penulis, E-mail:fekyreken90@gmail.com
}

\begin{abstract}
ABSTRAK
Penelitian ini bertujuan untuk : (1) menguji dan menganalisis pengaruh pemasaran digital melalui websites terhadap peningkatan penjualan pada Ciputra Tallasa JO Makassar. (2) menguji dan menganalisis pengaruh pemasaran digital melalui social media terhadap peningkatan penjualan pada Ciputra Tallasa JO Makassar. (3) menguji dan menganalisis pengaruh pemasaran digital melalui email marketing terhadap peningkatan penjualan pada Ciputra Tallasa JO Makassar. Sampel yang digunakan dalam penelitian ini adalah 40 Customer CitraLand Tallasa City Makassar yang melakukan pembelian unit secara online atau melalui digital marketing. Data diuji dengan menggunakan analsis regresi linear berganda melalui alat analisis SPSS. Hasil penelitian menunjukkan bahwa: (1) pemasaran digital melalui websites berpengaruh positif dan tidak signifikan terhadap peningkatan penjualan pada Ciputra Tallasa JO Makassar. (2) pemasaran digital melalui social media berpengaruh positif dan signifikan terhadap peningkatan penjualan pada Ciputra Tallasa JO Makassar. (3) pemasaran digital melalui email marketing berpengaruh positif dan tidak signifikan terhadap peningkatan penjualan pada Ciputra Tallasa JO Makassar.
\end{abstract}

Kata Kunci: Digital Marketing, Websites, Social Media, Email Marketing, Peningkatan Penjualan

\section{ABSTRACT}

This study aims to: (1) test and analyze the effect of digital marketing through websites on increasing sales at Ciputra Tallasa JO Makassar. (2) test and analyze the effect of digital marketing through social media on increasing sales at Ciputra Tallasa JO Makassar. (3) test and analyze the effect of digital marketing through email marketing on increasing sales at Ciputra Tallasa JO Makassar. The sample used in this study is 40 CitraLand Tallasa City Makassar customers who purchase units online or through digital marketing. Data were tested using multiple linear regression analysis through SPSS analysis tools. The results showed that: (1) digital marketing through websites had a positive and not significant effect on increasing sales at Ciputra Tallasa JO Makassar. (2) digital marketing through social media has a positive and significant effect on increasing sales at Ciputra Tallasa JO Makassar. (3) digital marketing through email marketing has a positive and insignificant effect on increasing sales at Ciputra Tallasa JO Makassar.

Keyword: Digital Marketing, Websites, Social Media, Email Marketing, Sales Increase 
Perkembangan teknologi informasi sangat berkembang pesat.Berbagai kegiatan bisnis kecil sampai besar memanfaatkan perkembangan ini untuk menjalankan usahanya.Banyaknya competitor menjadi pertimbangan bagi para pengusaha untuk masuk dalam persaingan yang sangat ketat (Pradiani, 2017). Strategi pemasaran dan media yang tepat digunakan untuk bisa meraih pasar yang dituju sehingga penjualan meningkat.Digital Marketing adalah salah satu media pemasaran yang saat ini sedang banyak diminati oleh masyarakat untuk mendukung berbagai kegiatan yang dilakukan. Mereka sedikit demi sedikit meninggalkan model pemasaran konvesional/tradisional beralih ke pemasaran modern yaitu digital marketing.

Terhadap digital marketing komunikasi dan transaksi dapat dilakukan setiap waktu dan bisa mengglobal atau mendunia (Gumilang, 2019). Dengan jumlah pengguna social media berbasis chat ini yang banyak dan semakin hari semakin faktor motivasi kerja, dan lingkungan kerja. Kinerja merupakan jawaban dari berhasil atau tidaknya tujuan organisasi yang telah ditetapkan. Kinerja berasal dari pengertian performance. Ada pula yang memberikan pengertian performance sebagai hasil kerja atau prestasi kerja. Menurut penelitian Sugianingrat dan Sarwana (Zahara, 2019), kinerja karyawan merupakan faktor yang sangat penting yang menentukan keberhasilan bisnis di berbagai bertambah membuka peluang bagi perusahaan property untuk mengembangkan pasarnya hanya melalui genggaman smartphone.

Pertumbuhan pengguna internet secara global mengalami peningkatan hingga 1 juta pengguna dibandingkan tahun 2018 lalu (Harahap, 2018). Pertumbuhan ini didapatkan dari orang-orang yang baru pertama kali menggunakan internet selama hidupnya. Pertumbuhan ini mengalami peningkatan sebesar 1.1 persen dibandingkan tahun lalu. Pertumbuhan pengguna internet ini pun diikuti dengan pertumbuhan internet menggunakan smartphone selama periode Januari 2018-Januari 2019 yang mengalami pertumbuhan 2.0 persen.

Di Indonesia sendiri, para pengguna aktif internet (per hari) menduduki peringkat ke-5.Posisi ini mengalami penurunan jika dibandingkan pada tahun sebelumnya berada di posisi 4 . Dimana rata-rata pengguna internet di Indonesia per harinya menghabiskan 8 jam 36 menit. Di bawah Fillipina, Brasil, Thailand dan Kolombia. Sedangkan untuk akses internet melalui smartphone, Indonesia berada di posisi ke-4 dengan rata-rata waktu yang dihabiskan untuk browsing melalui device ini adalah sekitar 4 jam 35 menit. Sedangkan para pengguna internet di Indonesia melalui yang mengakses melalui desktop atau computer hanya berkisar 4 jam dan membawa Indonesia pada posisi ke-15 secara global.

Data data tersebut sudah cukup menunjukkan bahwa pengguna internet akan terus meningkat seiring dengan perkembangan teknologi suatu negara serta semakin variatifnya smartphone. Jumlah ini tentu menunjukkan semakin banyaknya penggunan internet di seluruh dunia, perlu mendapatkan perhatian lebih terhadap para pelaku bisnis untuk segera memaksimalkan potensi pemasaran digital marketing untuk menumbuhkan bisnis baik untuk penjualan, pemasaran maupun branding.

Menurut (Susan \& Dann, 2011) online shop berasal dari kata online yaitu aktifitas mengakses internet dan berbelanja. Online shop adalah proses dimana konsumen membeli produk atau jasa melalui internet, yaitu melalui toko online yang ada pada 
internet. Berbelanja melalui media online merupakan penggunaan jasa melalui media internet dimana pembeli dapat melihat terlebih dahulu spesifikasi dan gambaran produk barang dan jasa yang akan dibeli melalui media yang telah dipromosikan oleh penjual. Kegiatan jual beli ini tidak memerlukan komunikasi dalam bentuk tatap muka secara langsung, melainkan dapat dilakukan melalui alat atau perantara berupa laptop/notebook, komputer, ataupun handphone yang tersambung dengan layanan akses internet. Dengan tunjangan media komunikasi yang saat ini serba canggih dan modern akan semakin mempermudah masyarakat unutk dapat melakukan berberlanja secaraonline.

Dengan adanya toko online, penjual dan pembeli bisa melakukan transaksi tanpa harus bertatap muka secara langsung. Hal ini menjadikan transaksi menjadi lebih cepat dan mudah, kapanpun dan dimanapun tinggal "klik" maka masyarakat bisa berbelanja dan memilih barang yang sesuai dengan minat masing-masing. Online shop ini dianggap cepat, nyaman dan praktis. Inilah yang meyebabkan banyaknya pengusaha yang memutuskan untuk menjajal bisnis online shop untuk dapat memenuhi banyak minat pembeli.

Fenomena internet dan jejaring sosial di Indonesia saat ini dimanfaatkan dengan munculnya berbagai peluang bisnis. Salah satu diantaranya yaitu internet sebagai Advertising Tool yang memiliki tujuan untuk mempromosikan dan menjual produk menggunakan iklan melalui internet dengan media sosial yang telah berkembang untuk melakukan kegiatan jual beli serta memberikan informasi suatu brand yang biasa disebut E-commerce (Arifin, 2003:101).Alasan jejaring sosial sangat tepat untuk dijadikan media dalam menjalankan bisins yaitu biaya yang dikeluarkan lebih murah, jangkauan pasarnya tanpa batas jarak dan waktu, dapat menjalin hubungan baik dengan pelanggan, pelanggan aktif, memberikan feedback, dan segala bentuk informasi dapat tersebar luas secara cepat. Penetrasi internet ini pula mengubah pola berbelanja masyarakat Indonesia sebagai pasar primadona bagi para pelaku $e$ commerce, terbukti menjamurnya bisnis e-commerce yang menjual berbagai jenis produk dan layanan jasa, baik perusahaan nasional maupun multi-nasional.

Dalam skala nasional promosi toko online yang menggunakan media sosial menjadi fenomena dalam pemasaran digital, banyak pengusaha yang menggunakan sarana ini sebagai penunjang pemasaran dan penjualan produk. Perusahaan Property di Makassar sendiri sedang maraknya menggunakan social media dalam melakukan promosi penjualan, dengan tujuan memperkenalkan produk usaha dan juga upaya untuk menarik perhatian konsumen. Bagi sebuah perusahaan, promosi merupakan hal yang sangat krusial dalam memperkenalkan bisnis dan produk kepada masyarakat. Dengan terus berkembangnya teknologi dan minat konsumsi dari masyarakat, maka dibutuhkan langkah-langkah promosi yang tepat sasaran oleh setiap perusahaan demi bertahan di tengan persaingan pasar.

Besarnya potensi digital marketing di Indonesia dimanfaatkan baik oleh beberapa perusahaan property. Social media digunakan keduanya dalam memasarkan produknya dengan perkembangan jejaring sosial kegiatan digital marketing pun dilakukan melalui chat app seperti Whatsapp. Sedangkan untuk penjualan online keduanya menggunakan Social Media. Untuk memperkuat kegiatan marketing tersebut, dibutuhkan strategi kegiatan promosi yang berfungsi untuk memperkenalkan, mengkomunikasikan, dan mempengaruhi konsumen untuk 
melakukan pembelian. Bantuan teknologi digital maka kegiatan digital marketing dan strategi bauran promosi pemasaran perusahaan dapat berjalan dengan efektif dan efisien. Saat ini konsumen cenderung membuka situs atau sosial media perusahaan hanya untuk melihat apa saja produk yang ditawarkan.

Selanjutnya mereka akan melakukan transaksi langsung secara offline. Akan tetapi sebisa mungkin perusahaan juga harus mampu membuat pelanggan mereka melakukan transaksi melalui online. Dalam hal ini peneliti melakukan penelitian terhadap perusahaan digital marketing Ciputra Tallasa JO dengan alasan perusahaan perlu melakukan beberapa cara media komunikasi dengan konsumen, melakukan transaksi secara secara online. Berdasarkan latar belakang diatas, peneliti menganggap bahwa penelitian ini menarik dilakukan dalam rangka memperkuat loyalitas dan menghubungkan dirinya dengan pelanggan. Dengan konsep yang menggunakan isi kontent dan strategi-strategi yang sangat berhubungan dengan target konsumen. Menarik untuk dilakukan penelitian dengan fokus utama untuk mengetahui bagaimana strategi digital marketing dalam membantu penjualan Ciputra Tallasa JO. Oleh karena itu peran digital marketing dalam sebuah perusahaan property sangat menarik untuk dikaji dan diteliti.

Seperti halnya dilakukan oleh Ciputra Tallasa JO dalam memasarkan produk property mereka apalagi dilihat banyaknya minat masyarakat untuk membeli suatu hunian yang dapat dijadikan tempat tinggal maupun investasi dalam membantu perputaran ekonomi di indonesia, bukan saja rumah tapi komersial business yang akan dipasarkan melalui digital marketing. Segmentasi pasarnya adalah para executive muda yang hidup dijaman millenial yang sering bergelut dengan dunia internet yang sering menggunakan social media.Berdasarkan alasan diatas penulis tertarik untuk melakukan penelitian apakah social media bagian dari digital marketing yang digunakan memberi pengaruh terhadap peningkatan penjualan property mereka.

\section{Kerangka Konseptual}

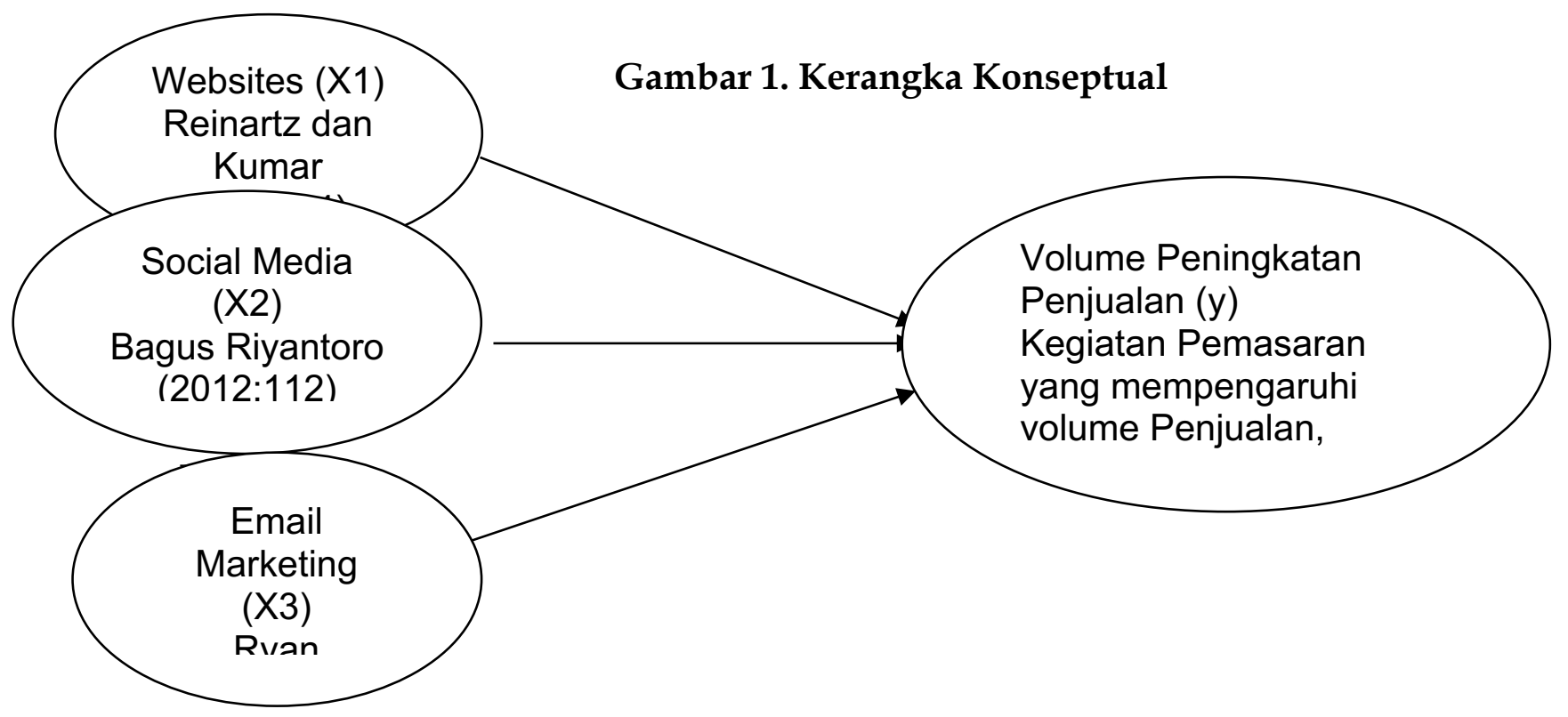




\section{Hipotesis}

Berdasarkan latar belakang masalah dan kajian teori maka hipotesis dalam penelitian ini yaitu :

1. Websites berpengaruh positif dan signifikan terhadap volume peningkatan penjualan pada Ciputra Tallasa JO.

2. Social Media berpengaruh positif dan signifikan terhadap volume peningkatan penjualan pada Ciputra Tallasa JO.

3. Email Marketing berpengaruh positif dan signifikan terhadap volume peningkatan penjualan pada Ciputra Tallasa JO.

Pendekatan penelitian ini adalah kuantitatif yang berguna untuk menganalisis bagaimana suatu variabel independen mempengaruhi variabel dependen dan berguna pada penelitian yang bersifat explanatory research dimana variabel independennya diperlakukan secara terkendali oleh peneliti untuk melihat dampaknya pada variabel dependennya. (Sugiyono, 2013)

Penelitian dilakukan di Kota Makassar, Provinsi Sulawesi Selatan. Tepatnya pada kantor Ciputra Tallasa JO yang beralamat di Jalan Tallasa Boulevard, Jalur Lingkar Barat Makassar. Alasan pemilihan lokasi karena Ciputra Tallasa JO merupakan perusahaan property terbesar di kota makassar dan dibawa naungan Ciputra Group yang dimana perusahaan property terbesar di Indonesia, faktor lain karena sudah mengadopsi sistem pemasaran digital marketing ditambah penulis bekerja di perusahaan tersebut.

\section{Pengujian Hipotesis}

a. Uji Koefisien Determinasi $\left(\mathrm{R}^{2}\right)$

Nilai $\mathrm{R}^{2}$ digunakan untuk mengukur seberapa jauh kemampuan model dalam menerangkan variasi variabel dependen. Pada penelitian ini yang digunakan adalah adjusted $\mathrm{R}^{2}$ dapat naik atau turun apabila satu variabel independen ditambahkan kedalam model. Nilai yang mendekati satu berarti variabelvariabel independen memberikan hamper semua informasi yang dibutuhkan untuk memprediksi variabel dependen (Ghozali, 2014)

b. Uji Regresi Simultan (Uji Statistik F)

Uji statistic F dilakukan dengan tujuan untuk menguji apakah keseluruhan variabel independen mempunyai pengaruh secara bersama-sama terhadap variabel dependen. Ghozali (2014:155). Pengujian simultan ini dilakukan dengan berpedoman pada hipotesis uji berikut :

$\mathrm{H}_{0} ; \beta_{\mathrm{I}}=0$ melawan $\mathrm{H}_{a} ; \beta \neq 0$

Kriteria Pengujian :

Jika $\mathrm{F}_{\text {hitung }}<\mathrm{F}_{\text {tabel }}$ atau $\mathrm{P}>0,05$ maka $\mathrm{H}_{0}$ diterima

Jika $\mathrm{F}_{\text {hitung }} \geq \mathrm{F}_{\text {tabel }}$ atau $\mathrm{P}<0,05$ maka $\mathrm{H}_{0}$ ditolak

Jika $\mathrm{H}_{\mathrm{O}}$ diterima, berarti secara simultan, semua koefisien tidak berbeda nyata nilainya dengan 0 pada tingkat kepercayaan 95\%. Dengan demikian, hasil analisis regresi tidak dapat dipakai untuk melakukan pendugaan secara statistic, seperti membuat ramalan mengukur korelasi dan determinasi. Sebaliknya jika $\mathrm{H}_{0}$ ditolak, berarti secara simultan (bersama-sama) semua koefisien regresi 
berbeda nyata nilainya dengan 0 pada tingkat kepercayaan 95\%. Dengan demikian, hasil analisis regresi dapat dipakai untuk melakukan pendugaan secara statistic.

c. Uji t (Persial)

Untuk mengetahui ada tidaknya pengaruh variable bebas terhadap variable terikat, maka dilakukan pengujian hipotesis yang diajukan pada penelitian ini. Metode pengujian terhadap hipotesis yang dilakukan pengujian secara persial menggunakan uji $t$. uji $t$ menunjukkan seberapa jauh pengaruhnya variable independen.

Untuk menguji apakah masing-masing variable bebas berpengaruh secara signifikan terhadap variable terikat secara persial dengan menentukan derajat kepercayaan $95 \%(\alpha=0,05)$ dan juga penerimaan atau penolakan hipotesis. Maka cara yang dilakukan adalah :

1) Ho: $b_{1}=0$, artinya variabel $X$ tidak mempunyai pengaruh yang signifikan secara persial terhadap variabel $Y$

2) Ha: $b_{1} \neq 0$, artinya variabel $X$ mempunyai pengaruh yang signifikan secara persial terhadap variabel $Y$

3) Taraf signifikan menggunakan 0.05

4) Dengan membandingkan thitung dengan table

Apabila $t$ hitung $>t$ kritis Ho diterima

Apabila $t$ hitung $<\mathrm{t}$ kritis Ho diterima

\section{HASTL DAN PEMBBAHASAN}

\section{Hasil}

Hipotesis diuji dengan menggunakan uji signifikansi parameter individual ( Uji Parsial ). Uji ini digunakan untuk menguji tingkat signifikansi pengaruh variabel independen yang terdiri dari pemasaran digital melalui websites, social media dan email marketing terhadap variabel dependen yaitu peningkatan penjualan secara parsial atau secara sendiri-sendiri. Pengambilan keputusan dilakukan berdasarkan perbandingan nilai $t$ hitung masing-masing koefisien $t$ regresi dengan $t$ tabel sesuai dengan tingkat signifikansi yang digunakan yaitu 0,05. Hasil uji signifikansi parameter individual ( Uji t ) disajikan pada tabel berikut ini:

\section{Coefficients}

\begin{tabular}{|c|c|c|c|c|c|c|}
\hline \multirow{2}{*}{\multicolumn{2}{|c|}{ Model }} & \multicolumn{2}{|c|}{ Unstandardized Coefficients } & \multirow{2}{*}{$\begin{array}{c}\text { Standardized } \\
\text { Coefficients } \\
\text { Beta }\end{array}$} & \multirow[b]{2}{*}{$t$} & \multirow[b]{2}{*}{ Sig. } \\
\hline & & $B$ & Std. Error & & & \\
\hline \multirow[t]{4}{*}{1} & (Constant) & 1,201 & 2,407 & & .499 &, 621 \\
\hline & Websites & .256 & .244 &, 196 & 1,049 &, 301 \\
\hline & Social Media &, 797 & 255 & .574 & 3,119 &, 004 \\
\hline & E-Mail Marketing &, 118 & 118 & 123 & 996 & 326 \\
\hline
\end{tabular}

Sumber: Data diolah 2020 
Untuk mengetahui besarnya pengaruh masing-masing variabel independen $(X 1, X 2$, X3) terhadap variabel dependen (Y) secara parsial, dapat dilakukan dengan membandingkan nilai t-hitung $>$ t-tabel (2.036) dan $a<0,05$ sebagaimana yang terlihat pada tabel sebelumnya. Untuk mengetahui lebih jelasnya dapat diuraikan sebagai berikut:

1. Hasil pengujian terhadap variabel websites (X1) menunjukkan bahwa nilai nilai t-hitung 1,049 < t-tabel 2,036 dan tingkat signifikan sebesar 0,301 > 0,05. Hasil penelitian menunjukkan bahwa variabel websites (X1) berpengaruh secara positif dan tidak signifikan terhadap peningkatan penjualan. Dengan demikian hipotesis yang diajukan ditolak.

2. Hasil pengujian terhadap variabel social media (X2) menunjukkan bahwa nilai nilai t-hitung 3,119 > t-tabel 2,036 dan tingkat signifikan sebesar 0,04<0,05. Hasil penelitian menunjukkan bahwa variabel social media (X2) berpengaruh secara positif dan signifikan terhadap peningkatan penjualan. Dengan demikian hipotesis yang diajukan diterima.

3. Hasil pengujian terhadap variabel emil marketing (X3) menunjukkan bahwa nilai nilai t-hitung 0,996 < t-tabel 2,036 dan tingkat signifikan sebesar 0,326 >0,05. Hasil penelitian menunjukkan bahwa variabel email marketing (X3) berpengaruh secara positif dan tidak signifikan terhadap peningkatan penjualan. Dengan demikian hipotesis yang diajukan ditolak.

\section{PEMBAHASAN}

Berdasarkan tujuan penelitian ini yaitu untuk mengetahui pengaruh variabel digital marketing melalui websites, social media dan email marketing terhadap peningkatan penjualan pada Ciputra Tallasa JO Makassar. Setelah dilakukan uji hipotesis secara parsial, maka ketiga variabel independen yaitu Websites (X1), Social Media (X2), dan Email Marketing (X3) berpengaruh positif terhadap peningkatan penjualan pada Ciputra Tallasa JO Makassar, akan tetapi hanya variabel social media (X2) yang berpengarus signifikan.

Adapun pembahasan mengenai pengaruh pengaruh variabel digital marketing melalui websites, social media dan email marketing terhadap peningkatan penjualan pada Ciputra Tallasa JO Makassar adalah sebagai berikut.

\section{Pengaruh Digital Marketing melalui Websites terhadap Peningkatan Penjualan pada Ciputra Tallasa JO Makassar}

Hasil penelitian hipotesis menunjukkan bahwa terdapat pengaruh positif antara digital marketing melalui websites terhadap peningkatan penjualan pada Ciputra Tallasa JO Makassar akan tetapi hasil tersebut tidak signifikan. Hasil ini diperoleh melalui hasil perhitungan nilai $\mathrm{t}$ hitung sebesar 1,049 yang lebih kecil dari nilai $\mathrm{t}$ tabel sebesar 2,036 dengan taraf signifikansi 0,301 yang lebih besar dari 0,05 sehingga hipotesis pertama ditolak (H1 ditolak).

Pengujian ini secara statistik dapat membuktikan bahwa variabel digital marketing melalui websites berpengaruh positif namun tidak signifikan terhadap peningkatan angka penjualan. Hal tersebut dapat terjadi dikarenakan kurangnya konsumen yang mengenal Citraland Tallasa city melalui websites, tidak aktifnya konsumen dalam melihat promosi di website, dan jarangnya perusahaan mengupdate info terbaru di 
websites. Setiap usaha promosi yang dilakukan melalui websites akan berdampak baik pada peningkatan penjualan namun tidak begitu memberikan pengaruh yang besar atau signifikan. Maksud dari pernyataan tersebut diatas adalah bahwa usaha promosi melalui websites bukan merupakan usaha yang sia-sia untuk dilakukan, meskipun tidak signifikan tapi promosi websites tetap dapat menunjang peningkatan dan pengenalan produk yang dipasarkan sehingga sebaiknya usaha ini tetap dilakukan.

Dalam konteks bisnis, (Alhasanah, 2019) menjelaskan bahwa internet membawa dampak transformasional yang menciptakan paradigma baru dalam bisnis, berupa Pemasaran Digital. Jika dulu dikenal model interaksi bisnis tradisional yang bersifat face to face, maka kini model interaksi itu telah berkembang ke arah interaksi modern berbasis elektronik atau e-commerce yang faceless, yakni sebuah model yang diperkenalkan oleh David C. Arnot dan Susan Bridgewater (2002) yang terbagi menjadi Business to Business (B2B), Business to Customer (B2C), dan Customer to Customer (C2C) dengan target akhir adalah terciptanya penjualan. Dalam dunia pemasaran saat ini sedang terkenal dengan era Pemasaran Digital, di mana pemasar kini tidak lagi terbatas dengan bentuk-bentuk iklan dengan menggunakan media konvensional, seperti media cetak saja, tetapi telah dapat memanfaatkan media digital.

Reinartz dan Kumar (2005) menambahkan bahwa melalui saluran digital, kita sebagai penjual dapat menawarkan kesempatan untuk mengefisiensikan pengeluaran untuk dapat menjalin hubungan dengan konsumen dan meningkatkan loyalitas konsumen. Termasuk dalam hal ini adalah peran digital marketing melalui websites, meskipun mungkin saat ini orang-orang kebanyakan lebih senang bergelut dengan media lain seperti media sosial yang mungkin lebih easy, fun, dan mungkin lebih banyak konten hiburan yang menyelingi proses pemasaran.

Secara keseluruhan, teori yang dikemukakan oleh Reinartz dan Kumar (2005) tersebut dapat dikatakan valid jika dihubungkan dengan hasil penelitian pendahulu dimana sebagian besar hasil penelitian terdahulu berhasil membuktikan bahwa websites memberikan dampak yang baik terhadap peningkatan penjualan dikarenakan websites menjadi media yang mampu mempertemukan penjual dengan pembeli dengan memotong pos biaya yang kemungkinan akan terjadi jika dilakukan melalu tatap langsung. Hasil penelitian ini pun berhasil memberikan bukti empiris yang menunjukkan bahwa hasil penelitian ini memiliki arah yang sejalan dengan teori yang dikemukakan oleh (Reinartz, Thomas dan Kumar, 2005) meskipun secara statistik pengaruh yang ditimbulkan tidak signifikan namun dapat dipastikan bahwa hasil penelitian ini sesuai dengan teori.

\section{Pengaruh Digital Marketing melalui Social Media terhadap Peningkatan Penjualan pada Ciputra Tallasa JO Makassar}

Hasil penelitian hipotesis menunjukkan bahwa terdapat pengaruh positif antara digital marketing melalui social media terhadap peningkatan penjualan pada Ciputra Tallasa JO Makassar dan menunjukkan hasil yang signifikan. Hasil ini diperoleh melalui hasil perhitungan nilai t hitung sebesar 3,119 yang lebih besar dari nilai $\mathrm{t}$ tabel sebesar 2,036 dengan taraf signifikansi 0,04 yang lebih kecil dari 0,05 
sehingga hipotesis kedua diterima (H2 diterima) sehingga dapat ditarik kesimpulan bahwa digital marketing melalui media sosial berpengaruh positif dan signifikan terhadap peningkatan penjualan pada Ciputra Tallasa JO Makassar.

Pengujian ini secara statistik dapat membuktikan bahwa variabel digital marketing melalui social media berpengaruh positif dan signifikan terhadap peningkatan penjualan. Hasil pengujian menunjukkan bahwa digital marketing melalui social media memperoleh nilai paling tinggi dengan tingkat signifikansi yang paling berpengaruh diantara variabel lainnya. Hal ini menunjukkan bahwa banyaknya konsumen yang mengenal produk Citraland Tallasa melalui akun sosial media, konsumen juga lebih sering melihat promosi di akun sosial media, juga aktifnya akun sosial media citraland memberi informasi terbaru dan mendetail. Hal ini berarti menandakan betapa pentingnya membangun pasar dalam social media.

Social media merupakan media paling berpengaruh dalam bisnis di era digital saat ini. Gunelius (2011:59-62) menyebutkan bahwa Social media merupakan bagian penting dari strategi penjualan, pelayanan, komunikasi, dan pemasaran yang lebih besar dan lebih lengkap serta merefleksikan dan menyesuaikan diri dengan produk dan jasa yang mereka tawarkan melalui interaksi di media social antara satu dengan yang lainnya serta menjalin hubungan dengan mereka. Social media yang dilakukan oleh suatu bisnis dapat mempengaruhi pemikiran seseorang yang akan berdampak pada pemikiran orang lainnya secara lebih luas sebelum melakukan proses pembelian.

Social media menjadi wadah paling cepat dalam membangun brand, selling, dan education of product. Bisnis yang bergerak di industri apapun, salah satu kunci kesuksesannya adalah dengan mengenal pelanggan lebih dekat, dan social media hadir menjadi solusi untuk hal ini. Sosial media membuat proses pengenalan ini menjadi lebih mudah dibandingkan dengan sebelumnya. Dengan perangkat pendukung yang ada setiap akun sosial media, kini bisa diketahui dengan terperinci mengenai siapa saja yang menjadi calon konsumen. Dengan target konsumen yang tepat diharapkan akan memberikan keuntungan lebih dari investasi yang telah dilakukan.

Sosial media merupakan cara yang mudah untuk mencari tahu lebih banyak mengenai pelanggan. Sosial media membantu menemukan konsumen baru dan memperluas target pasar, Selain itu social media memudahkan konsumen untuk memberikan feedback mengenai bisnis anda secara langsung. Social media untuk bisnis memberikan anda akses dengan feedback positif maupun negatif dari konsumen, yang merupakan informasi berharga dari sudut pandang konsumen.

Melalui social media, sebuah bisnis dapat mengembangkan target pasar dan selangkah lebih maju dari kompetitor lain. Social media menginformasikan hal yang penting dari kompetitor, sehingga dapat menentukan dan meningkatkan strategi pemasaran. Dengan cara ini, bisa menganalisa teknik apa saja yang digunakan oleh kompetitor dan melakukan hal yang lebih baik dari yang mereka lakukan. Selain itu sosial media dapat membantu meningkatkan pengunjung website dan ranking search engine. Informasi dapat dibagikan lebih cepat dengan social media. Selain itu, social media mampu meningkatkan brand awareness dan promosi dengan biaya yang relatif 
lebih rendah.

Hasil penelitian ini sesuai dengan penelitian yang dilakukan oleh (Riyantoro \& Harmoni, 2012) yang berhasil menemukan bahwa strategi pemasaran produk dapat lebih efektif jika dilakukan melalui social media. Hasil penelitian ini juga didukung oleh hasil penelitian yang dilakukan oleh (Eko \& Chandra Julia, 2019) yang menemukan bahwa promosi melalui social media sangat berpengaruh signifikan terhadap keputusan pembelian oleh pelanggan. Selain itu hasil penelitian ini menjadi bukti empiris yang sangat relefan dengan kondisi penjualan di era digital saat sekarang.

\section{Pengaruh Digital Marketing melalui Email Marketing terhadap Peningkatan Penjualan pada Ciputra Tallasa Makassar}

Hasil pengujian hipotesis menunjukkan bahwa terdapat pengaruh positif antara digital marketing melalui email marketing terhadap peningkatan penjualan pada Ciputra Tallasa JO Makassar akan tetapi hasil tersebut tidak signifikan. Hasil ini diperoleh melalui hasil perhitungan nilai t hitung sebesar 0,996 yang lebih kecil dari nilai t tabel sebesar 2,036 dengan taraf signifikansi 0,326 yang lebih besar dari 0,05 sehingga hipotesis ketiga ditolak (H3 ditolak). sehingga dapat ditarik kesimpulan bahwa digital marketing melalui email marketing berpengaruh positif dan tidak signifikan terhadap peningkatan penjualan pada Ciputra Tallasa JO Makassar. Mengapa hal itu terjadi karena beberapa temuan dilapangan bahwa beberapa customer menerima email yang sifatnya hanya meperkenalkan jenis-jenis produk property CitraLand Tallasa City secara umum dan tidak mendetail. Disamping itu email merupakan aplikasi media digital marketing yang tidak bersifat mobile friendly.

Secara statistik, pengujian ini membuktikan bahwa variabel digital marketing melalui email marketing berpengaruh positif namun tidak signifikan terhadap peningkatan angka penjualan. Hasil ini menunjukkan bahwa tidak banyak konsumen mengenal produk citraland melalui email, kemudian tidak semua konsumen mendapatkan informasi secara detail melalui email marketing, dan tidak aktifnya citraland mengirim promosi melalui email marketing.

Kegiatan pemasaran melalui email marketing tetap memberikan pengaruh poisitif terhadap peningkatan penjualan meskipun tidak signifikan. Sehingga pemasaran yang dilakukan melalui email marketing tidak merupakan kegiatan yang percuma jika perusahaan tetap menjalankan pemasaran melalui media ini. akan tetapi jika dibandingkan dengan variabel lain yang diuji dalam penelitian ini, variabel email marketing merupakan variabel dengan pengaruh terkecil diantara variabel social media dan websites.

Hasil penelitian ini cukup relevan dengan kondisi era digital saat ini. sebagian besar orang (konsumen) lebih tertarik untuk membuka websites dan menjajal social media dibandingkan harus membuka email jika tujuannya hanya untuk membeli barang atau suatu produk yang dibutuhkan. Salah satu alasan yang mungkin sejalan dengan kondisi tersebut adalah karena email merupakan media informasi yang cukup flat jika dibandingkan dengan websites yang lebih colorfull dan social media yang lengkap dengan konten hiburan yang menarik perhatian dan mampu membuat pelanggan atau konsumen betah menatap layar gadget mereka dalam waktu yang 
cukup lama sehingga proses pengenalan produk dan proses pemasaran lebih maksimal.

Email marketing memiliki rasio konversi yang cukup tinggi, namun email hanya memungkinkan seseorang terlibat dengan mereka yang telah memilih untuk berkomunikasi. Sebuah studi menunjukkan bahwa 57\% aktivitas konten share global terjadi di social media. Namun, hanya 4 persen share yang berasal dari email. Email marketing mungkin merupakan cara yang hebat untuk menjangkau pelanggan saat ini. Namun secara keseluruhan, saluran social media memiliki tingkat keterlibatan yang jauh lebih tinggi daripada email marketing. Akan tetapi Email Pemasaran masih menjadi alat yang penting untuk kegiatan pemasaran digital, yang dikirimkan dengan tujuan untuk menjaga hubungan antara konsumen yang sudah ada maupun calon konsumen yang bersedia menerima informasi lewat email teori dapat dikatakan valid jika dihubungkan dengan penelitian sebelumnya.

\section{KESIMPULAN}

Berdasarkan hasil penelitian dan pembahasan, maka dapat ditarik kesimpulan sebagai berikut:

1. Digital marketing melalui websites berpengaruh positif namun tidak signifikan terhadap peningkatan penjualan pada Ciputra Tallasa JO Makassar. Hal ini dapat terjadi dikarenakan bahwa websites menjadi media yang mampu mempertemukan penjual dengan pembeli tanpa harus melalui tatap langsung akan tetapi di era milineal saat ini orang-orang kebanyakan lebih senang bergelut dengan media lain seperti media sosial yang mungkin lebih easy, fun, dan mungkin lebih banyak konten hiburan yang menyelingi proses pemasaran.

2. Digital marketing melalui media sosial berpengaruh positif dan signifikan terhadap peningkatan penjualan pada Ciputra Tallasa JO Makassar. Hal ini dapat terjadi dikarenakan Social media yang dilakukan oleh suatu bisnis dapat mempengaruhi pemikiran seseorang yang akan berdampak pada pemikiran orang lainnya secara lebih luas sebelum melakukan proses pembelian.

3. Digital marketing melalui email marketing berpengaruh positif dan tidak signifikan terhadap peningkatan penjualan pada Ciputra Tallasa JO Makassar. Hal ini dapat terjadi dikarenakan sebagian besar orang (konsumen) lebih tertarik untuk membuka websites dan menjajal social media dibandingkan harus membuka email jika tujuannya hanya untuk membeli barang atau suatu produk yang dibutuhkan. Salah satu alasan yang mungkin sejalan dengan kondisi tersebut adalah karena email merupakan media informasi yang cukup flat jika dibandingkan dengan websites yang lebih colorfull dan social media yang lengkap dengan konten hiburan yang menarik perhatian dan mampu membuat pelanggan atau konsumen betah menatap layar gadget mereka dalam waktu yang cukup lama sehingga proses pengenalan produk dan proses pemasaran lebih maksimal.disamping itu Email marketing tidak bersifat mobile friendly. 
(Survei Pada Konsumen Www. Getscoop. Com). Jurnal Administrasi Bisnis, 15(2).

Dann, S., \& Dann, S. (2011). E-Marketing: Theory And Application. Macmillan International Higher Education.

Eko, J. C. P., \& Chandra, J. (2019). Pengaruh Strategi Pemasaran Melalui Sosial Mediadan Review Produk Pada Marketplace Shopee Terhadap Keputusan Pembelian (Studi Pada Remaja Di Indonesia).

Ghozali, I. (2014). Ekonometrika: Teori, Konsep Dan Aplikasi Dengan Ibm Spss 22. Semarang: Badan Penerbit Undip.

Gumilang, R. R. (2019). Implementasi Digital Marketing Terhadap Peningkatan Penjualan Hasil Home Industri. Coopetition: Jurnal Ilmiah Manajemen, 10(1), 9-14.

Harahap, D. A. (2018). Perilaku Belanja Online di Indonesia: Studi Kasus. JRMSIJurnal Riset Manajemen Sains Indonesia, 9(2), 193-213.

Jones, R. T., Robeson, M. S., Lauber, C. L., Hamady, M., Knight, R., \& Fierer, N. (2009). A Comprehensive Survey Of Soil Acidobacterial Diversity Using Pyrosequencing And Clone Library Analyses. The Isme Journal, 3(4), 442-453.

Pradiani, T. (2017). Pengaruh sistem pemasaran digital marketing terhadap peningkatan volume penjualan hasil industri rumahan. Jurnal Ilmiah Bisnis Dan Ekonomi Asia, 11(2), 46-53.

Reinartz, W., Thomas, J. S., \& Kumar, V. (2005). Balancing Acquisition And Retention Resources To Maximize Customer Profitability. Journal Of Marketing, 69(1), 6379.

Riyantoro, B., \& Harmoni, A. (2012). Pengukuran Efektivitas Pengembangan Desain Menggunakan Model Epic. Jurnal Efektivitas Iklan Melalui Jejaring Sosial Sebagai Salah Satu Strategi Pemasaran Keripik Pedas Maicih Dengan Menggunakan Metode Epic.

Sugiyono, P. D. (2013). Metode Penelitian Manajemen. Bandung: Alfabeta, Cv.

Zahara, A. (2019). Effect Of Individual Capacity, Workload And Work Environment On The Performance Of Employees (Doctoral Dissertation, Universitas Lampung). 